\title{
An Analysis of the Path to Cultivating and Practicing Socialist Core Values for College Students in the New Era
}

\author{
Fei Chen* \\ School of Marxism, Northwestern Polytechnical University; Nanyang Institute of Technology \\ ${ }^{*}$ Corresponding author. Email: 345348505@qq.com
}

\begin{abstract}
The core values of socialism are the mainstream values of our society, which embodies the common value thinking and value orientation of our people. The cultivation of socialist core values in colleges and universities is currently facing severe challenges. The cultivation of socialist core values in colleges and universities is not scientifically perfect. This article is based on the theoretical basis of systematically combing the literature and materials related to the socialist core values of college students in the new era. Analyze the problems in the practice of socialist core values, try to externalize the socialist core values by strengthening the construction of excellent traditional culture, focusing on guiding college students to conduct self-education, establishing a mechanism for the construction of socialist core values, and focusing on practice. Establishing a campus culture mechanism led by socialist core values and establishing a campus network guidance mechanism explores new paths for college students to cultivate and practice socialist core values, so that the socialist core values can truly arouse recognition and recognition among college students Resonance, creating new forms for college students'ideological and political education, exploring new methods, summarizing new experiences, making them internalized in the heart, externalized in behavior, solidified in the system, and integrated into the commonplace. This has strong practical value and contemporary significance.
\end{abstract}

Keywords: College students, Cultivation, Socialist core values, Path.

\section{CORRECTLY GRASP THE SCIENTIFIC CONNOTATION OF SOCIALIST CORE VALUES}

Marxism believes that the value as a philosophical category refers to the positive significance of the object to the subject on the basis of practice. The value of socialism answers the significance of socialism for the masses of the people to develop their own existence and realize their own liberation. The core values of socialism are based on the excellent traditional culture of the Chinese nation and the spirit of socialist reform and innovation. The spiritual refinement of socialist values involves people's basic understanding and views on socialism and socialist construction. Values are consistent with the world view and outlook on life. Once the values are formed, they will regulate, restrict and guide people's behavior. The core values of socialism are deeply rooted in the spirit and culture of the Chinese nation, and are the most enduring and profound strength of the Chinese nation. [1] Today, in the face of the weakening of mainstream values by cultural pluralism, the promotion and promotion of socialist values is not only an important content of cultural construction, but also an important political construction content related to socialist modernization and the great rejuvenation of the Chinese nation. The core values reflect the common value norms and standards of a country and a nation. Prosperity, democracy, civilization, and harmony are the inherent attributes of socialist modernization; freedom, equality, justice, and the rule of law are the guidelines for the goal of socialist modernization; patriotism , Dedication, honesty, and friendliness set the basic requirements for each citizen's literacy, and also reflect the personal values of socialism. In short, the core values of socialism fully present the values and goals of the current spiritual civilization construction. 


\section{THE TIME SIGNIFICANCE OF COLLEGE STUDENTS' CULTIVATION AND PRACTICE OF SOCIALIST CORE VALUES}

\subsection{The Inevitable Requirement of Training Newcomers in the Era of National Rejuvenation}

The report of the 19th National Congress of the Communist Party of China put forward: "It is necessary to focus on cultivating newcomers of the era who are responsible for national rejuvenation", [2] and cultivate and practice the core values of socialism. To take on the responsibility of national rejuvenation, we must have a deep understanding of who we are, where we came from, and where we are going. On the basis of inheriting the excellent Chinese traditional culture, the core values of socialism are based on the current practice of socialism with Chinese characteristics in China, facing the future to realize the dream of the great rejuvenation of the Chinese nation, and answering what kind of country we want to build and what kind of construction It is a major issue of what kind of society and what kind of citizens to cultivate. Cultivating college students' socialist core values can help college students to correctly understand the history of our country, the historical position and characteristics of the times we are now in, and point out the correct development direction, so that college students can fully understand the historical mission shouldered by them. The direction of its own development closely integrates the development of individuals, countries and society, realizes the resonance of individuals and society at the same frequency, and gathers strong youth energy for the realization of the Chinese dream of the great rejuvenation of the Chinese nation.

\subsection{An Important Way to Carry out the Fundamental Task of Building up People in Universities}

Lide Shuren is the foundation of colleges and universities. It deeply answers the fundamental question of "what kind of people to train, how to train them, and for whom". It determines the direction and training goals of colleges and universities, and also tests all the work of colleges and universities. The fundamental standard. "Core values are actually a kind of virtue, both personal virtue and great virtue, that is, national virtue and social virtue." [3] Therefore, in order to realize the fundamental goal of establishing virtue and fostering people, colleges and universities must first help students fully understand The socialist core values are the most concentrated and vivid embodiment of contemporary Chinese spirit, embodying the country's spiritual pursuit and social judging standards of right and wrong, and are the value reference, value follow and action guide for the country, society and individual behavior. The practice of core socialist values by college students is conducive to strengthening their confidence in taking the road of socialism with Chinese characteristics, promoting the modernization of national governance capabilities and governance systems, and helping college students to correctly understand and handle the relationship between individuals and others, the country and society. Really grow into a qualified successor and builder of the cause of socialism with Chinese characteristics.

\subsection{Promote the All-round Development of University Students}

Students are the future of the motherland and the hope of the nation. College students are in a period of growing up and becoming talents and it is also a critical period for the formation of college students' values, and they are easily affected by various values. Various values collide and influence each other, causing confusion to college students. At this time, their choices are very tested. Deeply comprehending the connotation of the core values of socialism and firmly grasping it can better guide college students to make the right choices on the road of life and grow into talents. Therefore, college ideological and political education must pay more attention to the socialist core values. Let college students strengthen their beliefs, distinguish right from wrong, study scientific knowledge, constantly enrich and improve themselves, constantly improve their ideological level and spiritual realm, promote their own comprehensive development, and devote themselves to socialist modernization with a more positive attitude Under construction.[4]

\section{THE MAIN PROBLEMS EXISTING IN THE CULTIVATION OF COLLEGE STUDENTS' SOCIALIST CORE VALUES}

\subsection{Ignore the Role of Excellent Traditional Culture}

The traditional culture of our country has a long history, a long history, and is profound and profound. It is a valuable asset for the Chinese people and has inestimable value. Excellent traditional culture has distinctive national characteristics, profound connotations and strong spiritual power, guiding us forward. Excellent traditional culture is the ideological source of the core values of socialism. The core values of socialism have absorbed the essence of traditional culture and developed them, such as the rise and fall of the world in traditional culture, the patriotic spirit of being responsible for each other, the spirit of continuous self-improvement, and the value of peace. The spirit of 
harmony and so on. However, the core value education conducted by colleges and universities for college students often ignores the excellent Chinese traditional culture. It is incomplete to talk about socialist core value education without traditional culture. Therefore, when colleges and universities carry out socialist core values education, they should attach importance to traditional culture and combine the beneficial ingredients in traditional culture to strengthen the penetration of college students and promote socialist core values education to achieve good results.

\subsection{College Students Lack Cognition and do not Know the Meaning}

The core values of socialism are the mainstream values that our country has adhered to for a long time, the value standard that the society has adhered to for a long time, and the main content of the current mainstream media propaganda and advocacy in our country. It is an important direction for the development of campus culture in our universities. However, there are many college students who have a low general understanding of socialist core values. Most students only know the name but do not know the meaning. They lack an understanding of the socialist core value system as a whole, especially the country from three different levels., The society and individuals have insufficient understanding of the different content proposed by the society, no serious and systematic study, and no deep awareness of the guiding role of the socialist core values on the development of the country, society, and individuals. As a result, the advocacy of the socialist core values remains only oral, did not really enter the heart, and did not arouse greater recognition and strong resonance in the hearts of college students. Of course, it will not exert its due effect, affecting the core values of socialism in the whole society, especially the special group of college students.

\subsection{The Negative Impact of the Internet}

The rapid development of the Internet has brought a huge impact on our study and life. While the Internet broadens our horizons, facilitates our lives, and strengthens our communication with the outside world, it also brings a series of negative effects. Because college students are in an important period of their own development, it is difficult to correctly screen and judge the external ideological trends, which will have a certain negative impact on the values of some college students. Some college students not only did not inherit the good qualities of tenacious hard work, hard work and simplicity, but under the influence of various negative information, they developed the bad habits of selfishness, weak sense of integrity, and self-centeredness, shaking the original values of college students, Which makes the values of college students deviate, which brings difficulties to the cultivation of the socialist core values of college students.

\section{THE REALIZATION PATH OF COLLEGE STUDENTS' CULTIVATION AND PRACTICE OF SOCIALIST CORE VALUES}

\subsection{Strengthen the Construction of Excellent Traditional Culture}

Excellent traditional culture is the ideological source of the core values of socialism. The core values of socialism draw on the essence and beneficial ingredients of traditional culture, and sublimate excellent traditional culture according to the requirements of the times. Therefore, we must attach importance to the role of excellent traditional culture and integrate excellent traditional culture into the education of college students' socialist core values. Colleges and universities integrate the traditional virtues of the Chinese nation, such as patriotism, diligence, thrift, economy, loyalty and filial piety, into the education of socialist core values, and carry out a series of social practice activities, such as going to nursing homes to serve orphaned elderly people, participating in voluntary services, etc. These educational forms It will be more accepted by college students, enhance their interest in learning the core values of socialism, so that college students understand and agree with the core values of socialism from the bottom of their hearts, so as to consciously practice the core values of socialism. Make full use of traditional festivals, folk customs, traditional handicrafts and other media to enhance the influence of college students and make them the inheritors and spreaders of Chinese excellent traditional culture.

\subsection{Pay Attention to Guiding College Students to Conduct Self-education}

The effective two-way interaction between the educator and the educated is the prerequisite for the realization of the educational effect. The teacher imparts knowledge in the classroom. Without the cooperation and acceptance of the students, the teacher's efforts will be futile. Therefore, the self-education of college students is particularly important. The ultimate goal of education is to guide college students to conduct self-education. The self-education of college students helps them to understand the core values of socialism deeply, and then they can recognize and support the core values of socialism in their hearts. Only on this basis can they consciously practice the core values of socialism. Schools can arrange some practical activities to allow college students to study independently, strengthen self-management, and cultivate the habit of independent thinking and independent problem solving. 
In this way, when a college student encounters a problem, the first time he does not ask for help from others, but seeks a solution by himself. Similarly, when learning the core values of socialism, they will deepen their own cognition of the core values of socialism, from which they can understand the connotation and charm of the core values of socialism. Use theory to guide practice, internalize as spiritual motivation and externalize as behavioral orientation.

\subsection{Establish a Campus Network Guidance Mechanism}

The campus network is the main way for students to understand the society. It plays a very important role in spreading the core values of socialism. It truly makes the campus network an effective way for students to develop their ideas. The establishment of a campus network guidance mechanism is also mainly divided into two parts. The first part is to strengthen the publicity of the school's official website, guide students to regularly pay attention to the content update of the campus website, and develop schools, departments, classes and other levels based on the idea of the campus website. Ideological exchange seminars use the Internet as a carrier to effectively educate the core values of socialism. From a static communication passive learning form to an interactive two-way active form, this method attracts the attention of students and makes students willing to accept and generate initiative Interest in learning. The second part is to strengthen the guidance of public opinion on the campus network. In important political events, the mainstream media of the school must speak up in a timely manner, dare to fight against evil forces, establish a correct public opinion guide, and actively strengthen the systematic and effective guidance of students' thinking, To guide college students to establish a correct network view and legal awareness from different levels of values, national laws, regulations, etc., so that students can know good and evil, can distinguish right from wrong, and firmly use socialist core values as the ideological guidance and unshakable.

\section{CONCLUSION}

The core values of socialism are rich in ideological connotation and scientific, which are essential to the current socialist modernization drive. The core values of socialism are rooted in the practice of socialism with Chinese characteristics, rooted in the excellent traditional culture of the Chinese nation, and internalized in the development process of the country, nation, and citizens. Today's ideological and cultural exchanges are turbulent, and the task of ideological and political construction is arduous. It is necessary to consolidate the guiding position of Marxism, promote the core values of socialism, and purify the ideological and political environment of colleges and universities. In the process of carrying out socialist core values education in colleges and universities, classroom education should be based on correct education guidance, innovative public opinion propaganda methods, and a platform for participation by college students to achieve a benign interaction among the school, teachers, and students. Finally, insist Combine theory with practice, build a practical education base, strengthen understanding and recognition in practice, continue to practice in practice, have the courage to innovate, and continuously promote the construction of socialist core values in colleges and universities, and become an active propagandist and practitioner.

\section{REFERENCES}

[1] Xi Jinping. Decisive victory to build a moderately prosperous society in an all-round way, and win the great victory of socialism with Chinese characteristics in the new era-Report at the 19th National Congress of the Communist Party of China [M]. Beijing: People's Publishing House, 2017. DOI:

[2] Xi Jinping. Decisive victory to build a moderately prosperous society in an all-round way and win the great victory of socialism with Chinese characteristics in the new era [M]. Beijing: People's Publishing House, 2017: 42.

[3] Xi Jinping. Xi Jinping talks about state governance [M]. Beijing: Foreign Languages Publishing House, 2014.

[4] Book Writing Group. The Nineteenth Party Congress Report Guidance Reader [M]. Beijing: People's Publishing House, 2017. 